\title{
Average Packing Charges for Florida Fresh Citrus, 2002-20031
}

Ronald P. Muraro²

A survey was sent to Florida fresh citrus packers to collect data on the average "packing charges" for the 2003 season. A total of nine packinghouses from both the Indian River and Interior production regions provided data for the survey. This is not a statistically chosen sample; therefore, the costs may not be representative of Florida's total citrus packinghouse industry. The participants were chosen because of their willingness to participate in the survey. The information reported were "packing charges," not actual packing costs.

The average packing charges are presented in 4/5-bushel carton equivalents. The total average packing charges include:

1. Materials Costs: mesh/plastic bags and labels/price lookup codes.

2. Labor Costs: supervisor/foreman labor, grading, palletizing, shipping, and general labor (e.g., payroll taxes, workers' compensation, and ground insurance).

3. Other Direct Packing Costs: fruit treating, power, lights, water, repairs, maintenance, and miscellaneous supplies.
4. Indirect Packing Costs: fire and casualty insurance, taxes, licenses, depreciation, and rent.

5. General and Administrative Costs: office personnel (payroll taxes and workers' compensation), packinghouse and general manager fees, and office equipment and supplies.

6. Selling Expenses: sales salaries, travel, telephones, telegraph, and brokerage fees.

7. Special Assessments: advertising taxes, inspection fees, Florida Citrus Packers, and Citrus Administrative Committee.

Total packing charges per 4/5-carton equivalent were collected for five variety categories: domestic grapefruit, export grapefruit, oranges, temples and tangelos, and tangerines. Along with the total packing charges, information was collected on Florida field-box bases for fruit drenching charges, packinghouse elimination charges, and hauling charges for fruit elimination to the juice processors.

A summary of the estimated average packing charges is presented in Table 1. The 2002-2003

1. This is EDIS document FE431, a publication of the Department of Food and Resource Economics, Florida Cooperative Extension Service, UF/IFAS, University of Florida, Gainesville, FL. Published October 2004. Please visit the EDIS website at http://edis.ifas.ufl.edu.

2. Ronald P. Muraro, Professor, Department of Food and Resource Economics, Citrus Research and Education Center, Lake Alfred, FL, Florida Cooperative Extension Service, UF/IFAS, University of Florida, Gainesville, FL.

The Institute of Food and Agricultural Sciences is an equal opportunity/affirmative action employer authorized to provide research, educational information and other services only to individuals and institutions that function without regard to race, color, sex, age, handicap, or national origin. For information on obtaining other extension publications, contact your county Cooperative Extension Service office. Florida Cooperative Extension Service/Institute of Food and Agricultural Sciences/University of Florida/Christine Taylor Waddill, Dean. 
average packing charges for the five variety

categories were: domestic grapefruit $(\$ 3.544$ per carton), export grapefruit ( $\$ 3.992$ per carton), oranges (\$3.731 per carton), temples and tangelos (\$4.214 per carton), and tangerines ( $\$ 4.733$ per carton). Fruit drenching charges ranged from $\$ 0.169$ per box for grapefruit to $\$ 0.178$ per box for the other three variety categories. Average packinghouse elimination charges were: $\$ 0.575$ per box for grapefruit; $\$ 0.60$ per box for oranges, temples, and tangelos; and $\$ 0.404$ per box for tangerines. Hauling charges for eliminations averaged $\$ 0.378 /$ box for grapefruit, $\$ 0.404$ per box for oranges, and $\$ 0.434$ per box for temples, tangelos, and tangerines.

Additional information on citrus budgeting and cost analysis and harvesting charges (picking, roadsiding, and hauling) can be obtained by contacting your County Extension Citrus Agent or by visiting the UF/IFAS EDIS website at http://edis.ifas.ufl.edu. 
Table 1. Estimated average packing charges for Florida citrus, 2002-2003.

\begin{tabular}{|c|c|c|c|c|c|}
\hline Charges & $\begin{array}{l}\text { Domestic } \\
\text { Grapefruit }\end{array}$ & $\begin{array}{l}\text { Export } \\
\text { Grapefruit }\end{array}$ & Oranges & $\begin{array}{r}\text { Temples \& } \\
\text { Tangelos }\end{array}$ & Tangerines \\
\hline \multirow{3}{*}{ Total Packing Charges* } & \multicolumn{5}{|c|}{ dollar per carton } \\
\hline & 3.544 & 3.992 & 3.731 & 4.214 & 4.733 \\
\hline & \multicolumn{5}{|c|}{ dollar per box } \\
\hline Drenching Charge & 0.169 & 0.169 & 0.178 & 0.178 & 0.178 \\
\hline $\begin{array}{l}\text { Packinghouse } \\
\text { Elimination Charge }\end{array}$ & 0.575 & 0.575 & 0.600 & 0.600 & 0.633 \\
\hline $\begin{array}{l}\text { Hauling Charges for } \\
\text { Eliminations }\end{array}$ & 0.378 & 0.378 & 0.404 & 0.434 & 0.434 \\
\hline \multicolumn{6}{|c|}{$\begin{array}{l}\text { * Total Packing Charges include: } \\
\text { 1. Materials Costs: mesh/plastic bags and labels/price lookup codes. } \\
\text { 2. Labor Costs: supervisor/foreman labor, grading, palletizing, shipping, and general labor (e.g., payroll taxes, workers' } \\
\text { compensation, and ground insurance). } \\
\text { 3. Other Direct Packing Costs: fruit treating, power, lights, water, repairs, maintenance, and miscellaneous supplies. } \\
\text { 4. Indirect Packing Costs: fire and casualty insurance, taxes, licenses, depreciation, and rent. } \\
\text { 5. General and Administrative Costs: office personnel (payroll taxes and workers' compensation), packinghouse and } \\
\text { general manager fees, and office equipment and supplies. } \\
\text { 6. Selling Expenses: sales salaries, travel, telephones, telegraph, and brokerage fees. }\end{array}$} \\
\hline
\end{tabular}

